\title{
Project Based Learning Enhances Student Quality in Vocational Education
}

\author{
Sri Sukamta1, Totok Sumaryanto Florentinus ${ }^{2}$, Rasdi Ekosiswoyo ${ }^{3}$, S. Martono ${ }^{4}$ \\ ${ }^{1,2,3,4}$ Graduate School, Universitas Negeri Semarang, Indonesia \\ Coresponding email: ssukamta2014@mail.unnes.ac.id
}

\begin{abstract}
21 st century human resource competition is getting tighter, including vocational teachers on vocational education. In micro vocational teachers are required to use the relevant learning model. One such model is the project based learning. The problem under study why vocational teachers should use project based learning models? In this journal we can explain some arguments that the project based learning: a) affect the creativity of students in creating a product, b) increase the frequency of attendance, c) cultivate student independence, d) have an attitude of responsibility, e) high-level thinking, f) expand access to student learning with diverse cultures. However, in order to optimize the implementation of this model, it is necessary to have prerequisites: a) time management, b) the selection of material and mastering the concept by the teacher, c) the process of systematic, creative and useful work. Based on the above exposures it is recommended that the vocational teacher be required to use a project based learning model. This can elevate the quality of students and win compete in the 21 st century.
\end{abstract}

Key words: Learning Model, Project Based Learning, Vocational Teachers

\section{Introduction}

The life of the 21st century is a life without boundaries, globalization, and the exploration of technology is very easy (Hartini, 2007). The 21st century requires knowledgeable, skilled, and innovative human resources. It requires educational institutions, especially vocational education to produce graduates who are able to compete with superior thinking ability to be ready to plunge into global society. Overcoming these challenges, vocational teachers need to innovate learning to make students more skilled.

Learning is defined as the process of student interaction with teachers and learning resources in a learning environment (Rahyubi, 2012), learning not only the process of student interaction with teachers but must also be characterized by changes in self (Sudjana, 2010). Another thing that must be considered in the learning process is a strategy to cause learning intentions in students. According to the (Sanjaya, 2006) one of its strategies is by doing student-centered learning. Student center is a way of teaching that is determined by the students themselves, by experiencing themselves, working alone or in groups, students become happy and grow interest to learn.

In developing critical and skilled thinking skills, it is necessary for teachers to use appropriate learning models in vocational schools. Learning model in question is a learning that contains four pillars of education set by UNESCO is learning to know, learning to do, learning to be and learning to live together. Based on the four pillars, the project based learning model is appropriate to develop critical thinking skills in vocational students. This is because the project based learning model requires students as a learning center (student center), given a project shaped problem and then they are required to complete it.

Based on the above background, the following problems are found: how can project based learning improve student quality in vocational education in the 21 st century? To address these issues in detail can be described in the sub sections below.

\section{Methods}

The descriptive analytic method was used in this study. According to (Aslichati, 2010) the purpose of descriptive research is to make a systematic, factual and accurate description of the facts and characteristics of a particular population.

The data used in this study consisted of the characteristics of the condition of the vocational students.

The steps of descriptive research in this study are: first, defining clearly and specifically the goals to be achieved, the facts and what characteristics need to be found. 
Second, designing the approach. In this study using the literature review approach. Third, conclude the results of several literature reviews that have been found.

\section{Results and Discussion}

\subsection{Learning Model of The $21^{\text {st }}$ Century}

Educational institutions need to consider the scope of the success of their graduates not only to be limited to academic ability, but rather to skills and skills that can help graduates compete in today's global and digital world (Dewi, 2015). New skills are needed to survive and compete in a rapidly changing digital world (Metiri, 2003). In line with that opinion, (Partnership, 2015) confirms that 21st century skills are formed from a solid understanding of content knowledge which is then sustained by the skills, skills and literacy needed by an individual to support his or her success both personally and professionally. Further described this 21 st century skill arises from an assumption that today individuals live and live in technology-laden environments, where there is an abundance of information, accelerated technological advances and new patterns of communication and collaboration. Success in the digital world is highly dependent on the skills essential to possess in the digital age, including critical thinking skills, problem solving, communicating and collaboration (Partnership, 2015).

\subsection{Vocational Education}

Vocational education is a balanced combination of theory and practice with the orientation of the readiness of graduates (Sumarto, 2009). In vocational education, the curriculum is concentrated on specialized vocational skills learning systems. Learners can directly develop their skills tailored to the needs of the field or field of tasks that will be faced. Basically vocational education is more education-oriented and more productive. Graduates of vocational education are expected to be competent and skilled at work. Vocational education is directed to print graduates who are ready to work according to the needs of today's workplace. Therefore, the 70 percent learning program is an industry practice.

\subsection{Vocational Teachers}

Improving the quality of education is influenced by various factors such as the quality of resources, the quality of teachers and learning managers, the quality of the learning process, the assessment system and quality control, and the ability of education managers to anticipate and handle the various influences of the educational environment.

If a vocational teacher can not keep up with these developments then it can not be said that the teacher is professional. A significant indicator in assessing individual preofesionalism in carrying out its professional duties as a vocational teacher is the suitability between skills and work that is able to teach learners thoroughly and correctly. Completely and correctly in providing the subject matter is very dependent on the mastery of teachers on the material being taught and how the teacher teaches the material with an effective learning model.

The passage of time has now entered the century of information and technology era, where a person or a vocational teacher must be able to respond quickly and effectively to changes based on his critical and creative thinking skills. Therefore, being a professional vocational teacher must have flexible intellectual skills, the ability to analyze information, and integrate various sources of knowledge to solve problems in order to respond to change quickly. Vocational education reform requires a substantive change in how the vocational field is taught to adapt to current circumstances, which therefore require substantive changes in professional vocational teacher development practices in all areas of expertise (Wening, 2014).

\subsection{Project Based Learning Model}

Learning models that can improve critical thinking, collaboration, communication and creative thinking skills are essential in $21 \mathrm{st}$ century education to cope with the increasingly tough competition of human resources. One of the best learning models to deal with human resource competition in the 21 st century is project based learning. Project based learning not only equips students with science but in the process of project work requires students to be able to implement their real-life understanding through teamwork. Project based learning is a learning approach controlled by students through teacher assistance. (Bell, 2010) explain that students determine their own 
research questions and then are guided by the teacher to conduct research, then the results of the project are presented to a pre-determined audience. Project based learning is an innovative learning approach that implements strategies that lead to the improvement of 21 st century skills (Dewi, 2015).

According to (Dewi, 2015) describes the 5 principles of project based learning as shown in the illustration below:

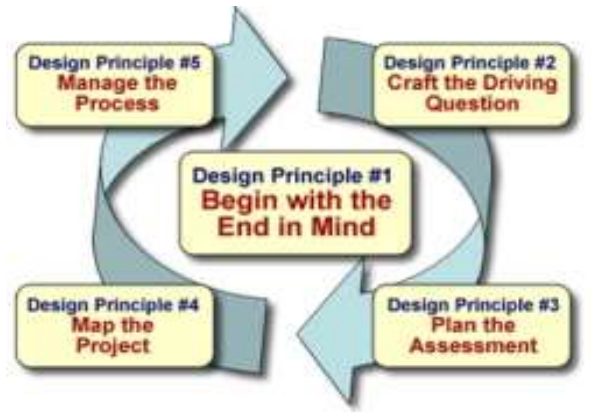

Figure 1. Principles of Project Based Learning

From the illustration above it can be seen that a project based learning should begin with a clear purpose for the product to be produced at the end of the project. Furthermore, the teacher should determine the driving question of the project before applying this project to the students. In addition, the type of assessment and the research flow needs to be determined from the outset to ensure direction of the project to be implemented by the students. The last principle to consider is how the teacher will manage the project's implementation in order to run smoothly in accordance with the intended purpose (Dewi, 2015). Project based learning has a variety of objectives including the development of students' positive attitudes, critical thinking skills, cooperation, and self-study skills (Petrosino, 2007). In this case, students are stimulated to use critical thinking skills that will help them build a community of learners who master collaborative learning content. With the implementation of project based learning, students are equipped with life skill skills that will be useful for his life in the future. In line with reference opinion (Petrosino, 2007). (Dewi, 2015) also explains that through project based learning students learn to work together and develop skills that directly relate to their needs personally, where they are required to solve real problems that are contextually very important for them.
In its implementation, project based learning emphasizes student-centered learning and places teachers as facilitators, while students work actively in small groups to teach each other and help their friends and shape their own knowledge (Eng, 2000). To that end, in project based learning students engage in meaningful interaction and cooperation that is rooted in the real world outside the classroom so as to enhance students' motivation to continue collaborating in solving problems and completing their projects (Jeon, 2005).

\subsection{Project Based Learning Enhances Student Quality Vocational Education}

According to the reference (The George, 2005), the stages in the project based learning model include six stages: (1) starting from the question, (2) designing the project activity, (3) creating an activity schedule, (4) monitoring the progress of the project activity, and (5) a reflection of experience gained that gives students the opportunity to link material content to real contexts, find concepts, apply concepts, cooperate in solving problems, and construct their own knowledge.

In the conventional learning model students are faced with a discussion process to solve problems without involving students in the learning planning process such as designing project activities, scheduling activities, and implementing projects conventional learning also has not provided an opportunity for students to complete the inquiry process as the discussion process is still under the guidance of teachers. This causes the students less enthusiastic in following the learning and learning process becomes less meaningful so that students' understanding of the lesson material is reduced which result in less than maximum learning outcomes.

This discussion is in line with some previous research results are as follows. Research by (Amanda, 2014) found that the application of project based learning models was able to provide a better understanding of concepts than conventional learning models.

(Baidowi, 2016) suggesting the results of the study can be concluded that the model of project based learning has a significant effect on the ability to write scientific papers geography of high school students. (Kamdi, 2010) conclude that the Characteristics of Project Based Learning applied in SMK in Malang form three configurations. The first 
configuration, a Project Based Learning model that places project work as a vehicle for technical skills development, and teacher role dominance in the project completion process is enormous. The second configuration, a Project Based Learning model that places project work as a vehicle for closer theoretical and practical learning and the third configuration, a project based learning model that places project work as a tool for integrating practical-learning learning, learning about contextual, collaborative, and large-scale autonomy solutions to students in decision making of project work completion. (Muam, 2017) say that project based learning has a positive impact on students in the translation class. With project based learning, many of the perceived benefits of the process are often in the form of collaborative learning. The strategy and model of the application of project based learning should be tailored to the allocation of different learning hours and student abilities. The lecturer's own attitudes related to his duty to engage in project based learning from start to finish should also be improved, improving collaboration between students and the intensity of interaction between students and lecturers.

(Thomas, 2000) say that there is some evidence that project based learning, in comparison to other instructional methods, has value for enhancing the quality of students' learning in subject matter areas, leading to the tentative claim that learning higher-level cognitive skills via project based learning is associated with increased capability on the part of students for applying those learnings in novel, problemsolving contexts. There is ample evidence that project based learning is an effective method for teaching students complex processes and procedures such as planning, communicating, problem solving, an decision making, although the studies that demonstrate these findings do not include comparison groups taught by competing methods.

Based on the discussion of the project based learning model as described above, there are implications of the findings as follows. First, to improve students' learning outcomes of vocations, teachers should change the learning paradigm from teacher centered to student centered. This proves that students who actively build their knowledge through the problem-solving process will have better thinking skills. The skills that students have will help students achieve optimal learning outcomes. Second, to achieve optimal learning outcomes in learning in vocational education, project based learning models can be applied as an alternative learning model. Project based learning can be implemented by providing problems related to the experience of the students. In order for project based learning activities to work effectively, teachers are required to define or design a project work that fosters a sense of wanting to research, solve problems, and high curiosity. In addition, there is a need for adequate school management and learning environments such as laboratories, and library rooms, to facilitate teachers and students in finding and exploring the information needed in the learning process so that teachers and students are able to apply project based learning models well.

\section{Conclusion}

Based on the above discussions, some conclusions can be drawn as follows: Project based learning can enhance the quality of vocational education students in the face of 21 st century human resource competition, The advantages of project based learning include: influencing the creativity of students in creating a product, increasing the frequency of student attendance, fostering student independence, more students have a responsible attitude, students can develop skills for high-level thinking, and expand student access to learning with diverse cultures, and the things to consider in the application of project based learning include the accuracy of time management, the preparation of material selection and mastery of concepts by teachers.

\section{References}

Amanda, N. W. Y., Subagia, I. W., \& Tika, I.N. (2014). Pengaruh Model Pembelajaran Berbasis Proyek Terhadap Hasil Belajar IPA Ditinjau Dari Self Efficacy Siswa. Program Pacasarjana Universitas Pendidikan Ganesha, 4.

Aslichati, L., Prasetyo, B., Irawan, P. (2010). Metodologi Penelitian Sosial. Jakarta: Universitas Terbuka.

Baidowi, A., Sumarmi, S., \& Amirudin, A. (2015). Pengaruh Model Pembelajaran 
Berbasis Proyek Terhadap Kemampuan Menulis Karya Ilmiah Geografi Siswa SMA. Jurnal Pendidikan Geografi, 20(1), 45-58.

Bell, S. (2010). Project Based Learning for the 21st Century: Skills for the Future. The Clearing House, 83: 39 -43. Taylor \& Francis Group.

Dewi, F. (2015). Proyek Buku Digital: Upaya Peningkatan Keterampilan Abad 21 Calon Guru Sekolah Dasar Melalui Model Pembelajaran Berbasis Proyek. Jurnal Metodik Didaktik. 9(2).

Eng. (2000). Can Asians Do PBLCDTL Brief 2(2). Retrieved May 2018 from http://www.cdtl.nus.edu.sg/brief/v3n3/sec2. html.

Hartini, A. (2017). Pengembangan Perangkat Pembelajaran Model Project Based Learning Untuk Meningkatkan Kemampuan Berpikir Kritis Siswa Sekolah Dasar. Elementary School Education Journal. 1(2a), 6-16.

Jeon, G., Debski, R., \& Wigglesworth, G. (2005). Oral Interaction Around Computers In The Project Oriented Call Classroom. Language Learning \& Technology, 9(3), 121-145. from http://1lt.msu.edu/vol9num3/jeon/.

Kamdi, W. (2010). Implementasi Project Based Learning di Sekolah Menengah Kejuruan. Jurnal Pendidikan Dan Pembelajaran, 17(April), 98-110.

Metiri Group. (2003). enGauge 21st century skills for 21st century learners. Retrieved October 29, 2010 from http://www.cwasd.k12.wi.us/highschl/news file1062 1.pdf.

Muam, A. (2017). Project Based Learning di Kelas Terjemahan Bahasa Asing untuk Pendidikan Vokasional. Lingua Aplicata,
$1(1), 17-35$.

Partnership for 21st Century Learning. (2015). P21 Partnership for 21st Century Learning. Partnership for 21 st Century Learning, 9. Retrieved from http://www.p21.org/documents/P21_Frame work_Definitions.pdf.

Petrosino, A. (2007). Houghton Mifflin College. Project Based Learning. Retrieved January 26, 2012, from http://college.cengage.com/education/resou rces/res project/students/c2007/index.html.

Rahyubi, H. (2012). Teori-teori Belajar dan Aplikasi Pembelajaran Motorik. Bandung: Nusa Media.

Sanjaya, W. (2006). Strategi Pembelajaran Berorientasi Standar Proses Pendidikan. Jakarta: Kencana Prenada Media Group.

Sudjana, N. (2010). Cara Belajar Aktif. Bandung: Sinar Baru Algensindo.

Sumarto, \& Nurhayati. (2009). Pendidikan Berkelanjutan Dalam Bidang Vokasi. Seminar Internasional, ISSN 1907-2066, $1-8$.

The George Lucas Educational Foundation. (2005). Instructional Module Project Based Learning. http://www.edutopia.org/modules/PBL/wha tpbl.php.

Thomas, J. (2000). A Review Of Research On Project-Based Learning. Http://Www.Bie.Org/Index.Php/Site/RE/Pb 1_research29.

Wening, S. (2014). Asesmen Berbasis Keterampilan Berpikir Kritis dan Kreatif untuk Menghasilkan Guru Vokasi Profesional di Masa Datang. Konvensi Nasional Asosiasi Pendidikan Teknologi dan Kejuruan (APTEKINDO) (pp. 490496). 